\title{
Misdiagnosis due to the Hook Effect in Prolactin Assay
}

\author{
Serkan Yener ${ }^{a}$ Abdurrahman Comlekci ${ }^{a} \quad$ Nuri Arda $^{b}$ Suleyman Men ${ }^{c}$ \\ Sena Yesil ${ }^{\mathrm{a}}$ \\ ${ }^{a}$ Department of Internal Medicine, Division of Endocrinology and Metabolism, and Departments of \\ ${ }^{b}$ Neurosurgery and ${ }^{C}$ Radiology, School of Medicine, Dokuz Eylul University, Izmir, Turkey
}

\section{Key Words}

Prolactin $\cdot$ Hook effect, misdiagnosis

\begin{abstract}
Objectives: To describe a patient who was misdiagnosed as having a nonfunctional pituitary tumor due to the hook effect on prolactin measurements. Clinical Presentation and Intervention: A 45-year-old female was admitted with visual disturbances, panhypopituitarism and central diabetes insipidus due to pituitary tumor recurrence. She had been operated 4 times earlier and received cranial irradiation for a suspected nonfunctional pituitary adenoma. Serum prolactin was moderately elevated $(164.5 \mathrm{ng} / \mathrm{ml})$, but increased markedly after 1:100 dilution to $14,640 \mathrm{ng} / \mathrm{ml}$. Diagnosis of a giant macroprolactinoma was made and cabergoline was started. Prolactin level normalized and a mild shrinkage of the tumor was achieved after 12 months of therapy. Conclusion: The hook effect must be kept in mind while evaluating a giant pituitary adenoma with moderately elevated prolactin levels. This way unnecessary surgical procedures or irradiation may be avoided.

Copyright $\odot 2008$ S. Karger AG, Basel
\end{abstract}

\section{Introduction}

Prolactinomas represent the most common type of secretory pituitary adenomas with a prevalence as high as $50 \%$ in some series [1]. Macroprolactinomas $(\geq 1 \mathrm{~cm})$ frequently present with serum prolactin levels in excess of $200 \mathrm{ng} / \mathrm{ml}$. Mild or moderate hyperprolactinemia may occur due to stalk compression by nonsecretory pituitary tumors or sellar lesions. In giant prolactinomas $(>4 \mathrm{~cm}$ in diameter or $>4 \mathrm{~cm}$ of suprasellar extension) the prolactin levels usually correlate with tumor size and the elevations observed in prolactin levels are distinct [1].

Despite the accuracy and specificity of immunoradiometric assay, enzyme immunoassay or immunochemoluminometric assays used for prolactin, high antigen levels may impair antigen-antibody binding known as 'hook effect' that results in serious underestimation of prolactin [2].

In this report we describe a patient presenting with a giant pituitary adenoma in which dilution testing of serum prolactin levels confirmed the presence of the hook effect; we also review the clinical characteristics of 17 similar patients that were reported previously in the literature. For this purpose a Pubmed (Medline) search was conducted with the following keywords: 'prolactin' and 
'hook effect'. Ten published reports on 17 patients were found. These findings are presented as a background to the patient reported here.

\section{Case Report}

A 45-year-old woman with enlargement of her pituitary tumor was referred to the Department of Internal Medicine, School of Medicine, Dokuz Eylul University, Izmir, Turkey, from a secondary health center. She had a medical history including 4 previous pituitary surgeries (transsphenoidal and transcranial) and pituitary irradiation (cumulative dose of 4,000 Gy after the first operation) in the previous 20 years. The pathological diagnosis of the tumor was missing. The patient reported that she had suffered from galactorrhea and blurring of vision before the first operation and she also stated that laboratory investigations including prolactin measurements had always been within the normal range. She had not been treated with dopamine agonists. During followup, surgeries had been performed because of the enlargement of the pituitary tumor.

On admission the patient was suffering from headache and visual disturbances. She did not have galactorrhea or breast tenderness. She had total loss of vision in the left eye since a previous operation. She had secondary amenorrhea and central diabetes insipidus. She was on phenytoin $(300 \mathrm{mg} /$ day) and desmopressin acetate-DDAVP $(20 \mu \mathrm{g} /$ day intranasally). The patient had no medical history of any other diseases. Her blood pressure was 110/70 $\mathrm{mm} \mathrm{Hg}$ and pulse rate was $72 / \mathrm{min}$. Physical examination revealed the presence of left amaurosis and lateral hemianopsia in the right eye. The light reflex was absent in the left eye and ophthalmologic examination showed optic atrophy. Right eye movements were normal. Deep tendon reflexes were normal and there was no pathological reflex.

Cranial magnetic resonance imaging (MRI) revealed the presence of a large and invasive tumor at the sella, its greatest diameter being $50 \mathrm{~mm}$. The mass invaded the optic chiasma, extending to the pontocerebellar region, left cavernous sinus and bilateral supraclinoid regions. Laboratory testing of serum demonstrated moderate hyperprolactinemia, prolactin $164.5 \mathrm{ng} / \mathrm{ml}$ (reference range: $1.9-25.0 \mathrm{ng} / \mathrm{ml})$, secondary hypothyroidism, $\mathrm{FT}_{4} 10.93$ $\mathrm{pmol} / \mathrm{l}$ (reference range: $10.29-24.45 \mathrm{pmol} / \mathrm{l}$ ), TSH $0.57 \mathrm{mU} / \mathrm{l}$ (reference range: $0.4-5.0 \mathrm{mU} / \mathrm{l})$, secondary hypogonadism, estradiol $<10 \mathrm{pmol} / \mathrm{l}$ (reference range: $73-550 \mathrm{pmol} / \mathrm{l}), \mathrm{FSH} 1.33 \mathrm{IU} / \mathrm{l}$ (reference range: $4-13 \mathrm{IU} / \mathrm{l}$ ), LH $0.25 \mathrm{IU} / 1$ (reference range: $1.68-15.0$ $\mathrm{IU} / \mathrm{l})$ and secondary adrenal insufficiency, $8.00 \mathrm{a} . \mathrm{m}$. cortisol 29.79 $\mathrm{nmol} / \mathrm{l}$ (reference range: $140-690 \mathrm{nmol} / \mathrm{l})$, ACTH $<10 \mathrm{pg} / \mathrm{ml}$ (reference range: $9-52 \mathrm{pg} / \mathrm{ml}$ ). Renal function, liver function, serum electrolytes and urine density were all within the reference range. Glucocorticoid replacement was started with prednisolone 15 $\mathrm{mg} /$ day postoperatively. Because of the discrepancy between the serum prolactin level and the size of the pituitary mass, serum samples were retested for prolactin after 1/100 dilution. This gave a serum prolactin level of $14,640 \mathrm{ng} / \mathrm{ml}$. The patient was given the dopamine agonist cabergoline $3 \mathrm{mg} /$ week. Levothyroxine $50 \mu \mathrm{g} /$ day was initiated in the second week of glucocorticoid therapy and prednisolone dose was gradually tapered to $7.5 \mathrm{mg} /$ day. Six weeks after the initiation of cabergoline the prolactin levels decreased to $3,660 \mathrm{ng} / \mathrm{ml}$. In the $24 \mathrm{th}$ week of therapy the prolactin
Table 1. Characteristics of patients with macroprolactinoma and the hook effect

\begin{tabular}{|c|c|c|}
\hline Characteristics & $\begin{array}{l}\text { Patients reported } \\
\text { in the literature } \\
{[2-11]}\end{array}$ & $\begin{array}{l}\text { Patient } \\
\text { in this } \\
\text { report }\end{array}$ \\
\hline Gender, female/male & $3 / 15$ & female \\
\hline Mean age, years & $38.5(24-65)$ & 45 \\
\hline Prolactin level before dilution, $\mathrm{ng} / \mathrm{ml}$ & $106(31-212)$ & 164 \\
\hline Prolactin level after dilution, $\mathrm{ng} / \mathrm{ml}$ & $48,386(2,222-280,000)$ & 14,640 \\
\hline $\begin{array}{l}\text { Average difference in prolactin } \\
\text { value from dilution, } \mathrm{ng} / \mathrm{ml}\end{array}$ & $35,503(2,167-279,969)$ & 14,534 \\
\hline FSH-LH deficiency & $13 / 17$ & yes \\
\hline Galactorrhea & $1 / 17$ & no \\
\hline Visual disturbance & $16 / 17$ & yes \\
\hline ACTH deficiency & $4 / 17$ & yes \\
\hline TSH deficiency & $6 / 17$ & yes \\
\hline Preoperative diagnosis & $9 / 17$ & no \\
\hline
\end{tabular}

$\mathrm{ACTH}=$ Adrenocorticotropic hormone; $\mathrm{FSH}=$ follicle-stimulating hormone; $\mathrm{LH}=$ luteinizing hormone; $\mathrm{TSH}=$ thyroid-stimulating hormone.

level was $1.2 \mathrm{ng} / \mathrm{ml}$ and the size of the pituitary mass was stable as seen in MRI. The prolactin level was $1.5 \mathrm{ng} / \mathrm{ml}$ in the first year of therapy and MRI findings were consistent with mild regression of the tumor mass observed in the coronal $\mathrm{T}_{1}$-weighted gadolinium-enhanced MRI scan. The patient is being followed with cabergoline $3 \mathrm{mg} /$ week, prednisolone $5 \mathrm{mg} /$ day, levothyroxine $50 \mu \mathrm{g} /$ day and desmopressin acetate-DDAVP (20 $\mu \mathrm{g} /$ day intranasally).

\section{Discussion}

An accurate prolactin measurement is essential for the differential diagnosis of pituitary tumors as false-negative results lead to surgical procedures or pituitary irradiation with serious morbidities. There are previous reports of patients with giant pituitary tumors showing mild or moderately elevated prolactin levels because of the hook effect [2-11].

A review of the literature on giant prolactinomas and the hook effect showed 11 reports of 18 patients, including our present report (table 1). Male dominance is manifest $(83.3 \%)$ and the mean age of patients is 38.5 years. The symptoms of hyperprolactinemia in men (usually impotence and infertility) are obscure when compared to women and this may lead to the delayed recognition and consequently existence of larger tumors [1].

The mean prolactin level of patients before dilution was $106 \mathrm{ng} / \mathrm{ml}$. This level is considered to be a gray area in the management of pituitary macroadenomas as the 
differentiation of stalk compression by a nonfunctional macroadenoma from a macroprolactinoma cannot easily be done with this moderately elevated prolactin level.

Galactorrhea was present in 2/18 (11.1\%). The male dominance of the patient group probably explained the low incidence of galactorrhea. Visual disturbance is one of the major complaints of patients on admission. Hypogonadism is a frequent manifestation of hyperprolactinemia. In this particular patient population hypogonadotropic hypogonadism is prominent (the rate of FSHLH deficiency is $77 \%$ ) because of the compression of a giant tumor on pituitary cells. The secondary adrenocortical deficiency rate in this patient group is $27.8 \%$ and the secondary hypothyroidism rate is $38.9 \%$. It is interesting to note that only $39 \%(7 / 18)$ of the patients could be diagnosed before the operation. We found that tumor size, age, gender or pre- and postdilution prolactin levels had no significant effects $(\mathrm{p}>0.05)$ on the duration prior to diagnosis. All patients except 1 were treated with dopamine agonists and both prolactin levels and tumor size were demonstrated to decrease after initiation of therapy. These drugs normalize serum prolactin levels and can reduce the tumor size in most patients. Tumor shrinkage may not start for several months but it is a continuous process [1]. Significant reduction of the tumor mass in the present patient was achieved in the 1st year of therapy.

\section{Conclusion}

In patients presenting with mild or moderately high plasma prolactin levels, serum samples should be diluted before repeating the assay. This will help to distinguish a nonfunctional pituitary adenoma causing stalk compression from a prolactin-secreting tumor and to avoid unnecessary surgical procedures or pituitary irradiation.

\section{References}

1 Casanueva FF, Molitch ME, Schlechte JA, Abs R, Bonert V, Bronstein MD, Brue T, Cappabianca $\mathrm{P}$, Colao A, Fahlbusch R, Fideleff $\mathrm{H}$, Hadani M, Kelly P, Kleinberg D, Laws E, Marek J, Scanlon M, Sobrinho LG, Wass JA, Giustina A: Guidelines of the Pituitary Society for the diagnosis and management of prolactinomas. Clin Endocrinol (Oxf) 2006; 65:265-273.

-2 Schofl C, Schofl-Siegert B, Karstens JH, Bremer M, Lenarz T, Cuarezma JS, Samii M, von zur Muhlen A, Brabant G: Falsely low serum prolactin in two cases of invasive macroprolactinoma. Pituitary 2002;5:261265.

> Al Sifri SN, Raef H: The hook effect in prolactin immunoassays. Saudi Med J 2004;25: 656-659.
4 Barkan AL, Chandler WF: Giant pituitary prolactinoma with falsely low serum prolactin: the pitfall of the 'high-dose hook effect': case report. Neurosurgery 1998;42:913-915; discussion 915-916.

5 Comtois R, Robert F, Hardy J: Immunoradiometric assays may miss high prolactin levels. Ann Intern Med 1993;119:173.

-6 Delgrange E, de Hertogh R, Vankrieken L, Maiter D: Potential hook effect in prolactin assay in patients with giant prolactinoma. Clin Endocrinol (Oxf) 1996;45:506-507.

$\checkmark 7$ Fleseriu M, Lee M, Pineyro MM, Skugor M, Reddy SK, Siraj ES, Hamrahian AH: Giant invasive pituitary prolactinoma with falsely low serum prolactin: the significance of 'hook effect'. J Neurooncol 2006;79:41-43.

$>8$ Frieze TW, Mong DP, Koops MK: 'Hook effect' in prolactinomas: case report and review of literature. Endocr Pract 2002;8:296303.
Petakov MS, Damjanovic SS, Nikolic-Durovic MM, Dragojlovic ZL, Obradovic S, Gligorovic MS, Simic MZ, Popovic VP: Pituitary adenomas secreting large amounts of prolactin may give false low values in immunoradiometric assays: the hook effect. J Endocrinol Invest 1998;21:184-188.

10 St-Jean E, Blain F, Comtois R: High prolactin levels may be missed by immunoradiometric assay in patients with macroprolactinomas. Clin Endocrinol (Oxf) 1996;44:305-309.

11 Unnikrishnan AG, Rajaratnam S, Seshadri MS, Kanagasapabathy AS, Stephen DC: The 'hook effect' on serum prolactin estimation in a patient with macroprolactinoma. Neurol India 2001;49:78-80. 